In this groundbreaking work, urban anthropologist Rae Bridgman explores in careful and intimate detail the perspectives of the women who work and live at Savard's, a unique shelter for homeless women. Bridgman uses the design and development of Savard's - a housing model developed by women for women - as an opportunity to document the project's original vision and what happened once it opened. There are few rules at Savard's. Women may come and go as they wish, and referrals to other services are made only when a woman has indicated interest in taking action on her own behalf. It is a model that aims to provide a safe haven for the chronically homeless.

The study traces the evolution of this type of shelter, providing qualitative research and useful analysis for academics, policy-makers, service providers, and activists. Based on many hours of participant observation as well as interviews and staff records, Safe Haven presents a distinct picture of the chronically homeless and those on the frontlines of this lifesaving service.

RAE bRIDGMan is Associate Dean (Research) and Associate Professor in the Department of City Planning, Faculty of Architecture, University of Manitoba. 
For the women who have lived and worked at Savard's

and

For my brother, Ross Anderson 


\section{Safe Haven}

\section{The Story of a Shelter for Homeless Women}

\section{Rae Bridgman}


www.utppublishing.com

(C) University of Toronto Press Incorporated 2003

Toronto Buffalo London

Printed in Canada

ISBN 0-8020-4240-6 (cloth)

ISBN 0-8020-8084-7 (paper)

()

Printed on acid-free paper

\section{National Library of Canada Cataloguing in Publication}

Bridgman, Rae

Safe Haven : the story of a shelter for homeless women / Rae Bridgman.

Includes bibliographical references and index.

ISBN 0-8020-4240-6 (bound). ISBN 0-8020-8084-7 (pbk.)

1. Savard's (Toronto, Ont.) 2. Homeless women - Housing -

Ontario - Toronto. 3. Women's shelters - Ontario - Toronto. I. Title.

HV4510.T6B75 $2003 \quad 362.83^{\prime} 83^{\prime} 09713541 \quad$ C2003-900155-5

This book has been published with the help of a grant from the Humanities and Social Sciences Federation of Canada, using funds provided by the Social Sciences and Humanities Research Council of Canada.

University of Toronto Press acknowledges the financial assistance to its publishing program of the Canada Council for the Arts and the Ontario Arts Council.

University of Toronto Press acknowledges the financial support for its publishing activities of the Government of Canada through the Book Publishing Industry Development Program (BPIDP). 